\title{
Three new subterranean diving beetles (Coleoptera: Dytiscidae) from the Yeelirrie groundwater calcretes, Western Australia, and their distribution between several calcrete deposits including a potential mine site
}

\author{
Stefan M. Eberhard ${ }^{1,2,3,}$, , Chris H.S. Watts ${ }^{4}$, Shae K. Callan ${ }^{1,5}$ and Remko Leijs ${ }^{4,6}$ \\ 1 Subterranean Ecology Pty Ltd, 227 Coningham Road, Coningham, Tasmania 7054, Australia. \\ 2 Honorary Associate, Western Australian Museum, 49 Kew Street, Welshpool 6106, Australia. \\ 3 University of New South Wales, Connected Waters Initiative Research Centre, 110 King Street, \\ Manly Vale 2093, Australia. \\ ${ }^{4}$ South Australian Museum, GPO Box 234. Adelaide, South Australia 5001, Australia. \\ ${ }^{5}$ Biologic Environmental Survey, PO Box 179 Floreat, Western Australia 6014, Australia. \\ ${ }^{6}$ School of Biological Sciences, Flinders University, GPO Box 2100, Adelaide, South Australia 5001, \\ Australia. \\ * Corresponding author: stefan@subterraneanecology.com.au
}

\begin{abstract}
Three new species of stygobitic Dytiscidae are described from groundwater calcretes in the Yilgarn region of Western Australia; Paroster angustus sp. nov., Limbodessus yeelirrieensis sp. nov. and Limbodessus odysseus sp. nov. As is the case in most Yilgarn stygobitic beetles the three species are eyeless, apterous, uniformly light testaceous and do not overlap in body length. All three species are short range endemics with their distribution restricted to a series of geologically discontinuous groundwater calcrete deposits occupying a linear extent of approximately 60 kilometres on Yeelirrie Station in the upper reaches of the Carey Palaeoriver system. The sympatric occurrence of the three species at one of the calcrete deposits is consistent with speciation, differentiation in body-size, and distribution patterns observed at numerous other calcretes in the Yilgarn region. Limbodessus odysseus has a wider distribution range than the other two species within the Yeelirrie groundwater system, possibly related to its smaller body size which may facilitate its dispersal and colonisation of interstitial or sub-karstic calcrete habitats. DNA sequencing established that the two Limbodessus species from Yeelirirrie are more closely related to species from calcretes in adjacent palaeochannels than to each other. A proposed uranium mine and associated aquifer dewatering activities would impact $42 \%$ of the core stygofauna habitat and $60 \%$ of the recorded distribution range of Paroster angustus sp. nov. and Limbodessus yeelirrieensis sp. nov. The impact of this amount of habitat removal and watertable lowering on the long term viability of the surviving populations of these two dytiscid species, and their associated stygofauna community, is unknown and cannot be predicted with any confidence.
\end{abstract}

KEYWORDS: Paroster, Limbodessus, stygofauna, stygobitic, short range endemic, genetics, environmental impact assessment, aquifer, dewatering

urn:Isid:zoobank.org:pub:66446A9D-D351-457E-A9D6-514753C841BC 


\section{INTRODUCTION}

Groundwater of (semi-) arid Western Australia is known as a globally significant hotspot for subterranean biodiversity (Humphreys 2008; Eberhard et al. 2009; Guzik et al. 2011). Most of this rich diversity has been discovered in the last 20 years in two main geographic regions, the Pilbara craton and the northern Yilgarn craton. In the semi-arid northern Yilgarn there occur hundreds of isolated groundwater calcretes developed along palaeoriver systems (Morgan 1993; Mann and Horwitz 1996). Development of these calcretes was initiated during dry climatic conditions in the Oligocene and has continued during subsequent arid phases of the Late Miocene and Pliocene onwards (Morgan 1993). The calcrete aquifers have a well-developed karstic porosity and therefore provide an ideal habitat for stygofauna (aquatic subterranean fauna). The detection of stygofauna in these calcretes is only possible owing to the existence of numerous wells and bores drilled for groundwater supply to pastoral stations, or for mineral exploration purposes. Around one-half of approximately 150 major calcrete islands in the northern Yilgarn have been sampled for stygofauna, and while the survey effort to date has generally been of reconnaissance intensity with $<10$ bores sampled inside most calcretes (Subterranean Ecology 2011), many new species have been discovered since the first collections were made in 1998.

The Yilgarn stygofauna comprises many species of copepods (Karanovic et al. 2015), ostracods (Karanovic 2008), parabathynellids (Abrams et al. 2012), amphipods (Bradford et al. 2010; King et al. 2012), isopods (Taiti and Humphreys 2001; Cooper et al. 2008), oligochaetes (Subterranean Ecology 2011), and dytiscid beetles (Watts and Humphreys 2009 and references within). Genetic and morphological studies on these taxonomic groups have confirmed that individual calcretes are equivalent to closed island habitats which have been isolated for millions of years by increasing climatic aridity (Cooper et al. 2002, 2008; Leys et al. 2003, 2012; Guzik et al. 2008; Leys and Watts 2008). Each calcrete aquifer functions as a biogeographic island and many species are short-range endemics (SREs) confined to a single calcrete (Cooper et al. 2002). The unique faunas of 77 calcretes have been listed as priority ecological communities (PECs) by the Western Australian Department of Parks and Wildlife (2014). The mean area of these calcretes is 90.8 square kilometres $\left(\mathrm{km}^{2}\right)$ (range $0.89-2,205 \mathrm{~km}^{2}$ ) and some of these distinct calcretes are only one kilometre $(\mathrm{km})$ apart (Harvey et al. 2011). The relatively small area harbouring each of these PECs makes them vulnerable to species loss and habitat degradation such as from mining and aquifer dewatering.

The stygobitic carnivorous water beetles (Dytiscidae) are the flagship taxa of the Yilgarn PECs. Over 90 species belonging either to the Hydroporini genus Paroster Sharp or to the Bidessini genus Limbodessus Guignot, have been formally described to date, making the Yilgarn a global hotspot for this group (Humphreys
2008; Watts and Humphreys 2009). In groundwater calcretes where dytiscids have been found, there typically occurs two or three sympatric or parapatric species belonging to either or both genera, and within any individual calcrete the coexisting species typically fall within non-overlapping size classes (viz. one largesized, one medium-sized, and one small-sized species) which may be an adaptive response towards partitioning of prey resources (Vergnon et al. 2013).

In this paper we describe three new species of Dytiscidae discovered during a pre-mining environmental impact assessment survey of stygofauna in the Yeelirrie groundwater calcretes in the northern Yilgarn. The impetus for the study came from a proposal by BHP Billiton Yeelirrie Development Company Pty Ltd to develop a uranium mine which would involve aquifer dewatering and potential impact on stygofauna. We describe the observed dytiscid distribution patterns in relation to the local geological mapping and groundwater salinity and briefly discuss the results of DNA sequencing.

\section{METHODS}

\section{STUDY AREA}

The greater Yeelirrie calcrete archipelago comprises an elongate cluster of geologically discontinuous groundwater calcrete islands and islets occupying a linear extent of approximately 60 kilometres in the upper reaches of the southern branch of the Carey Palaeoriver system in the northern Yilgarn (Figure 1). The Yeelirrie area includes surficial pedogenic (soilformed) calcrete and deeper non-pedogenic dolocrete formed at the subsurface water table. In parts of the calcrete system the surficial calcrete and dolocrete are vertically continuous but in other parts they are developed independently so that a near surface calcrete expression does not necessarily confirm the presence of underlying saturated dolocrete (Cameco Australia Pty Ltd 2015). The areas of calcrete are rarely uniform and comprise a variable mixture of calcrete, alluvium/ colluvium and clays.

The calcrete island and islet habitats are geologically isolated from each other by Quaternary alluvium/ colluvium albeit the various lithologic strata are hydrologically connected by groundwater flow along the palaeoriver channel which runs from northwest to southeast (Figure 1). While there exists groundwater connectivity between the calcretes via the alluvium/ colluvium, the potential habitat for stygofauna in the latter is limited to interstitial (inter-granular) porosity whereas the dolocretes contain solution-enlarged karstic cavities up to several centimetres in diameter which are interconnected and provide larger habitable spaces optimal for stygofauna. The thickness of saturated calcrete is mostly 3-5 metres (m) but is up to $13 \mathrm{~m}$ thick in the northwest. The carbonate-dominated water chemistry shows an overall gradient in salinity from 1-2 grams per litre $(\mathrm{g} / \mathrm{L})$ in the northwest to $10-25 \mathrm{~g} / \mathrm{L}$ 
in the southeast, but is highly variable vertically and horizontally, and can vary more than an order of magnitude over tens of metres (Cameco Australia Pty Ltd 2015). The highly variable salinity and patchy non-uniform lithology create a highly heterogeneous subterranean habitat.

The central and largest calcrete body, where the proposed mine and dewatering operation is situated, is approximately $17 \mathrm{~km}$ in length and up to three $\mathrm{km}$ wide, and the southeast calcrete is of similar size (Figure 1). Further southeast, are the Yeelirrie playa and Albion Downs calcretes. The northwest calcretes are smaller and more fragmented; all are less than five $\mathrm{km}$ in length and one $\mathrm{km}$ in width. The distance between calcrete bodies within the study area ranged from approximately one to six $\mathrm{km}$.

\section{SAMPLING}

Five sampling sectors were designated along the palaeochannel, and a sixth sector covering the surrounding granitic sandplains (Figure 1). The palaeochannel sectors coincided with the broad geographic clustering and alignment of calcrete deposits from northwest to southeast. Within each sector there existed a number of lines of holes drilled for mineral exploration and groundwater survey, in addition to isolated pastoral water bores and wells. The central calcrete body was subdivided into two sub-sectors (central-outside $0.5 \mathrm{~m}$ drawdown, central-inside $0.5 \mathrm{~m}$ drawdown) to distinguish the area located inside the potential impact zone of the proposed uranium mine (defined by the proposed pit and modelled 0.5 $\mathrm{m}$ drawdown contour, from Cameco Pty Ltd 2015) from the area located outside the potential impact zone (Figure 1). The southeast calcrete sector was also situated within the $-0.5 \mathrm{~m}$ drawdown contour. Although natural annual fluctuations of groundwater levels at Yeelirrie are probably $<1 \mathrm{~m}$, on account of the relative thinness of the saturated calcrete in most of the drawdown area at Yeelirrie, a precautionary threshold of $>0.5 \mathrm{~m}$ was identified as the point when groundwater drawdown may result in enough loss of stygofauna habitat to have significant conservation effects (Cameco Pty Ltd 2015).

More than one-half of the overall survey effort $(62 \%$ of 642 samples) was concentrated in areas outside of the potential mine impact area. Around 95 (37\%) of the sampled bores were located within the modelled $-0.5 \mathrm{~m}$ aquifer drawdown contours, which included the proposed mine pit, and around 162 bores (63\%) were located outside the potential mine impact area.

Six field sampling campaigns conducted between March 2009 and September 2010 sampled 257 groundwater bores (cased and slotted), mineral exploration drill holes (uncased), and pastoral bores/ wells (Figure 1). The majority of bores and drill holes were located in the palaeochannel sediments and constructed in transect lines perpendicular to the palaeochannel, with closely spaced transects in the central calcrete deposit and fewer transects in the smaller calcrete deposits located northwest and southeast of the central deposit (Figure 1). Twenty-four pastoral bores / wells were sampled in the granitic sandplain, mostly on the northern side of the palaeochannel. Most holes were sampled on more than one occasion, and holes yielding high abundances of stygofauna were targeted on repeated occasions (up to five).

Net hauling was the main method employed to capture stygofauna (317 samples), supplemented by opportunistic pump sampling undertaken in a few newly constructed bores during routine hydrological testing (26 samples). Dytiscids and other stygofauna were also collected as by-catch during scrape sampling for troglofauna in uncased drill holes which intersected the water table (299 samples).

The standard net hauling procedure used in Western Australia for environmental assessment surveys (EPA 2007; Eberhard et al. 2009) employs six hauls of the entire water column within each bore or well on each sampling occasion, using a 50 micron $(\mu \mathrm{m})$ mesh plankton net with an aperture of suitable diameter to fit within each bore (between 25-150 millimetres). A lead weight and sample vial (10 or 35 millilitres) was attached to the bottom of each net then lowered to the bottom of the bore on a line then hauled up through the water column. The retrieved sample was emptied into a jug of water, and following the sixth haul the sample was elutriated to remove coarse sediment and filtered back through the net.

The scraping method (Halse and Pearson 2014) is targeted towards troglofauna in the vadose zone above the water table and involves scraping the sides of uncased drill holes with a stygofauna net to dislodge any troglofauna on the sides of the hole. Four scrapes of the vadose profile were conducted to cover each quarter of the drill hole, and in holes intersecting the water table the net was dipped just below the water surface $(<1$ $\mathrm{m})$ on each scrape to collect dislodged troglofauna and stygofauna as by-catch.

Pump sampling involved placing a $50 \mu \mathrm{m}$ mesh plankton net over the pump outlet during routine hydrological pump testing using either a high-flow Grundfos ${ }^{\circledR}$ MP1 submersible pump with a $2 \mathrm{~mm}$ stoneguard over the intake, or a low-flow airbladder pump with a $6 \mathrm{~mm}$ intake mesh. Pumps were positioned at the top of the slotted interval in each bore with highflow pumping rates between 3-20 litres per minute (L/ min) and low-flow pumping rate approximately $0.12 \mathrm{~L} / \mathrm{min}$. The volume sampled from each bore depended upon aquifer yield and ranged from 7 to $600 \mathrm{~L}$ during high-flow pumping and 0.45 to $0.6 \mathrm{~L}$ during lowflow pumping. High-flow and low-flow samples from each bore were combined.

At each bore sampled, the depth to the watertable and total bore depth were estimated by counting the number of revolutions of the line spool during net hauling. The number of revolutions was then multiplied by the average circumference of the line spool $(0.63 \mathrm{~m})$. A bailer was used to collect a groundwater sample 


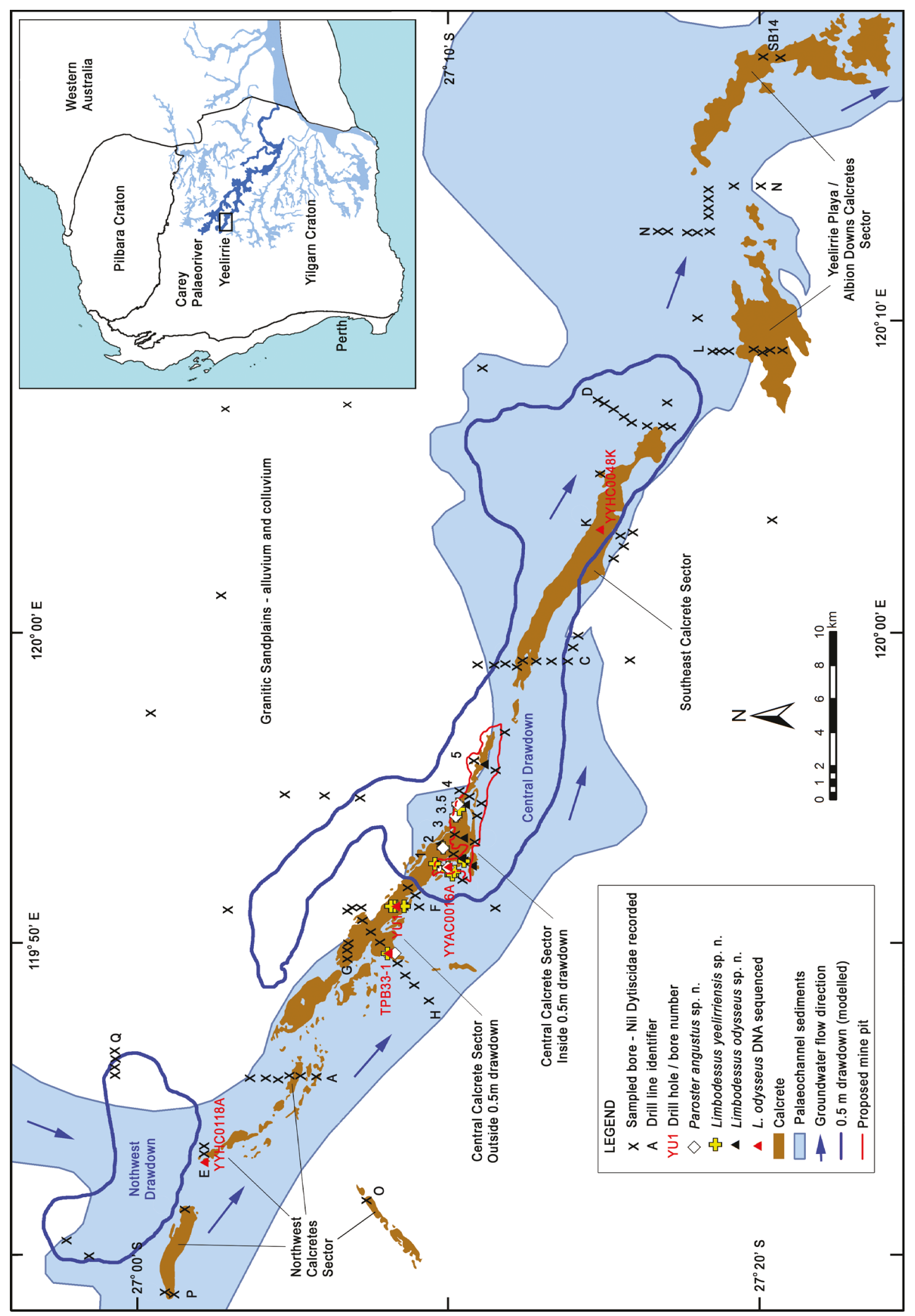

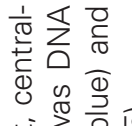

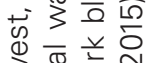

这曹

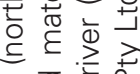

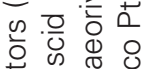

ब

을 बे

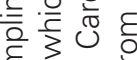

ल

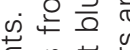

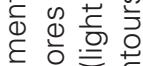

응 잉

बे

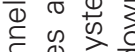

के $\stackrel{\oplus}{=}$ के

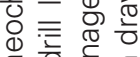

$\frac{\pi}{\pi}$ 需 $E$

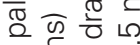

응 $\sum_{0}$

更

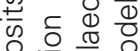

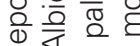

क w

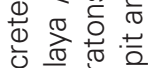

$\frac{\pi}{\pi} \frac{\pi}{2} \frac{\pi}{0} \frac{\pi}{0}$

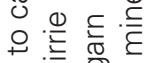

등 웡

元击 $\frac{0}{0}$ 응

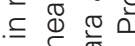

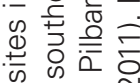

ธ

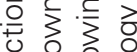

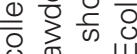

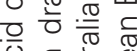

记

苛号文

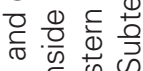

o . त

赔要了

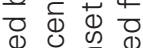

है

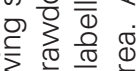

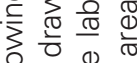

क ह 항 을

『

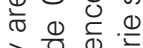

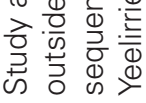

产 
from about one metre below the water surface and field physico-chemistry (temperature, $\mathrm{pH}$, and electrical conductivity) were measured using either a 'TPT' or 'WTW' brand field water meter (Subterranean Ecology 2011).

All field samples were preserved in pre-chilled $100 \%$ ethanol, labelled, sealed, and refrigerated for transport to the laboratory. Dytiscid specimens were sorted from the preserved field samples using a Leica M250C binocular microscope. All specimens are deposited in the collections of the Western Australian Museum (WAM) and South Australian Museum (SAMA).

A small number of specimens were DNA sequenced to confirm the morphological delimitation of adult and larval species, and examine regional phylogeographic relationships. Preliminary genetic analysis of Yeelirrie Dytiscidae was undertaken by Helix Molecular Solutions Pty Ltd, examining a 492 bp (DNA barcoding) fragment of the mitochondrial DNA gene cytochrome oxidase subunit 1 (COI). Subsequent analysis was undertaken by the South Australian Museum examining the 5' end of the COI gene, to facilitate regional comparisons with a data set of more than 90 subterranean species from the Northern Yilgarn and Murchison regions. To enable comparisons with the results by Helix, the specimens sent to the SAM were also PCR amplified using primers for the barcoding fragment of the COI gene. Overall, the sequenced material comprised 12 specimens including one paratype of each species and additional material representing L. odysseus (5 specimens), L. yeelirriensis (3) and $P$. angustus (1). DNA-sequences have been submitted to GenBank (Accession Nos KU549158 to KU549170).

\section{RESULTS}

\section{SURVEY EFFORT AND DISTRIBUTION PATTERNS}

Dytiscidae were collected from only 30 of the 257 bores and wells sampled. All bores which yielded dytiscids were located in the palaeochannel sediments mapped as calcrete. No dytiscids were collected from bores located in the palaeochannel alluvium / colluvium, nor in the granitic sandplain sediments (Figure 1). Almost all of the bores which yielded dytiscids were located in the central calcrete body ( 27 bores) and the three remaining bores were in the northwest ( 2 bores) and southeast calcrete bodies (1 bore). Dytiscids were not detected in the Albion Downs calcretes.

Altogether, 101 dytiscid specimens were collected during the survey and almost all (98 specimens) came from the central calcrete even though substantial survey effort was spread across the other palaeochannel sectors, which together accounted for $59 \%$ of all bores and $65 \%$ of all net haul samples. Of the 98 specimens collected from the central calcrete, more than two-thirds (69\%) came from within the proposed mine pit and dewatering area.

In comparing the capture success of net hauling versus scrape methods, there was considerable variability between sectors (range 0.01 to 0.53 dytiscids per net haul sample) but across all sectors (excluding those without dytiscids) the scrape method outperformed net hauling ( 0.25 versus 0.18 dytiscids per sample). In the net haul or scrape samples which yielded dytiscids, the number of individuals collected ranged from 1 to 10 and the average was 1.70 individuals per sample. No quantitative interpretation can be made on the capture results from the opportunistic pump sampling because of the unavoidable high variation in the sample volume which could be pumped from different bores.

Limbodessus odysseus was the most abundant and widely distributed species, with 49 individuals recovered from 19 bores, predominantly in the central calcrete and with two geographic outliers in the northwest and southeast calcretes, overall spanning a linear range of some $43.5 \mathrm{~km}$. In contrast, L. yeelirriensis $(36$ individuals in 15 bores) and P. angustus (16 individuals in 11 bores) were only detected in the central calcrete (Figure 1). In the central calcrete, three sampled bores contained all three species together, and in 11 bores two species (all three combinations) were found.

\section{GROUNDWATER ENVIRONMENT}

The range in selected groundwater environmental attributes recorded in bores from which dytiscids were collected, compared with all bores sampled, is shown in Table 1. Dytiscids were collected from bores where the water table ranged from 1.0 to 16.0 metres below ground surface and bore water temperature between 22.2 and $27.5 \mathrm{C}$. The electrical conductivity (EC) in bores with dytiscids ranged from 2.3 to 37.1 milli-Siemens per centimetre $(\mathrm{mS} / \mathrm{cm})$, and $\mathrm{pH} 7.00$ to 8.32 . The highest $\mathrm{pH}$ and EC recorded during the survey was 9.81 and 106.0 $\mathrm{mS} / \mathrm{cm}$ respectively.

Range (minimum - maximum) in groundwater environmental attributes recorded in bores from which dytiscids were collected, compared with all bores sampled. $N=$ number of sampled bores, $E C=$ electrical conductivity, $\mathrm{mbgl}=$ metres below ground level.

\begin{tabular}{llllll} 
& $N$ Bores & Depth to water table $(\mathrm{mbgl})$ & Temp $\left({ }^{\circ} \mathrm{C}\right)$ & $\mathrm{EC}(\mathrm{mS} / \mathrm{cm})$ & $\mathrm{pH}$ \\
\hline Bores with Dytiscids & 29 & $1.0-16.0$ & $22.2-27.5$ & $2.3-37.1$ & $7.00-8.32$ \\
All Bores & 257 & $0.5-29.6$ & $17.1-29.5$ & $0.31-106.0$ & $6.47-9.81$ \\
\hline
\end{tabular}


SYSTEMATICS

\section{Family Dytiscidae Leach, 1815}

Tribe Hydroporini Aubé, 1836

Genus Paroster Sharp, 1882

Paroster Sharp, 1882: 391.

\section{TYPE SPECIES}

Hydroporus insculptilis Clark, 1862 by subsequent designation of Guignot (1946).

\section{DIAGNOSIS}

Small size, 1.0-5.0 mm; clypeus not bordered; pronotum and elytra without stria; elytral epipleuron without basal cavity; meta coxal process very narrow not covering bases of trochanters, metacoxal lines well separated.

\section{Paroster angustus sp. nov.}

Figures 2-9

urn:Isid:zoobank.org:act:8AFFCB5F-F9CA-4B4A-885F16C0EF476D65

\section{MATERIAL EXAMINED}

Holotype

Australia: Western Australia: Yilgarn, Carey Palaeodrainage, Yeelirrie Station, 1 đิ seLN6620, 1-Sep2009 Bore YU2, 270814.15"S 1195111.41"E, collected by Subterranean Ecology Pty Ltd. Genbank Accession No. KU549169. WAM R90975.

\section{Paratypes}

Australia: Western Australia: Yilgarn, Carey Palaeodrainage, Yeelirrie Station, all collected by Subterranean Ecology Pty Ltd: 1 ㅇ seLN8340 16-Mar2010 Bore YYAC170, 27¹013.85"S 1195405.92"E; $1 \delta$ and 1 q seLN7415 12-Nov-2009 Bore YYAC35, 270958.56"S 1195226.36"E; 1 q seLN8346 16-Mar2009 Bore YYAC1007C, 270949.56"S 1195304.33"E. All SAMA.

\section{Other material}

Australia: Western Australia: Yilgarn, Carey Palaeodrainage, Yeelirrie Station, all collected by Subterranean Ecology Pty Ltd: 5 spec. seLN6480, 11Mar-2009, Bore TPB33-1, 270801.8"S 1194940.38"E; 1 spec. seLN6655, 12-Nov-2009, Bore YYAC0018C, $27^{\circ} 0941.75^{\prime S}$ 1195229.02"E, Genbank Accession No. KU549161; 1 spec. seLN8548a, 21-Mar-2010, Bore YYAC1007A, 270949.56"S 1195304.33"E; 1spec. seLN7679, 11-Jan-2010, Bore YYAC1007C, $27^{\circ} 0949.56 " \mathrm{~S} 119^{\circ} 5304.33^{\prime \prime E} ; 1$ spec. seLN7422, 12Nov-2009, Bore YYAC170, 27¹013.85"S 1195405.92"E; 1 spec. seLN7435, 12-Nov-2009, Bore YYAC248, $27^{\circ} 1020.35^{\prime \prime S} 119^{\circ} 5418.59 " \mathrm{E} ; 2$ spec. seLN7322 and 1 spec. seLN7391, both 12-Nov-2009, Bore YYAC284, 27023.6"S 1195424.73"E; 1 spec. seLN7391, 12Nov-2009, Bore YYAC284; 1 spec. seLN8391, 17-Mar2010, Bore YYAC285, 27017.84"S 1195428.4"E; 2 spec. seLN7639, 11-Jan-2010 and 1 spec. seLN8363, 16-Mar-2010, and 1 spec. seLN7128, 21-Mar-2010, all Bore YYAC35, 270958.56"S 119 5226.36"E; 4 spec. seLN8483a, 15-Mar-2010, Bore YYD26, 27007.23"S $119^{\circ} 5212.42 " E$. All WAM.

\section{DESCRIPTION}

Habitus. Length $3.9 \mathrm{~mm}$; strongly elongate, weakly constricted at junction of pronotum/elytra; uniformly light testaceous; hindwing vestigial, reduced to tiny flap.

Head. Relatively large, about as wide as elytra; smooth, weak reticulation, a few moderate sized small punctures inwards from base of antennae and a longitudinal row inwards from eye remnant; sides converging towards anterior; eye remnant reduced to two short sutures. Antenna moderately elongate, segments 1 and 2 cylindrical, segment 3 about as long as segment 2, narrower in basal half, segments 4-10 subequal in length slightly bulbous on both inside and outside apical angles, , segment 11 1.8x length of segment 10 , thinner, bluntly pointed. Maxillary palpus thin, elongate, segment 4 about as long as segments 2 and 3 combined.

Pronotum. Not much narrower than elytra; anteriolateral angles projecting forward; sides narrowing somewhat until just in front of base, posterolateral angles rounded; a few scattered large punctures towards anterior margin; a few long setae at sides particularly towards front; moderately strongly reticulate.

Elytra. Not fused, lacking inner ridges; elongate, parallel sided, about $4 \mathrm{x}$ as long as pronotum; smooth, shiny, reticulation weak, weaker than on pronotum; with a few small punctures, a few slightly larger punctures with long setae, larger and denser towards sides and apex. Epipleuron moderately differentiated, broad in anterior fifth, virtually absent along rest of elytron.

Ventral surface. Prosternal process strongly narrowed between coxae, not reaching mesoventrite, apical half with sides subparallel, tip weakly pointed, arched in lateral view with highest point (viewed ventrally) between coxae. Mesocoxae in contact in midline. Metaventrite projecting forward in midline; its lateral extensions ('wings') thin; narrowly rounded in midline behind. Metacoxal plates large, metacoxal lines weak, well separated, weakly diverging in front quarter, reaching nearly to mesosternum; sparsely covered with very small punctures, moderately reticulate; closely adpressed to ventrite 1 . Segments 1 and 2 fused, sutural lines distinct.

Legs. Protarsus segment 1 slight, segment 2 strongly expanded, segment 3 less so, deeply bilobed, segment 4 small, segment 5 elongate about as long as basal two segments, segments 1 to 3 with adhesive setae; claws 
short and simple. Mesotrochanter rather small with a few very fine setae at apex; mesofemur with row of 5 stout spines along hind edge in basal half (Figure 5); mesotarsus about as long as protarsus. Metatrochanter broad, apex pointed, well away from metafemur (Figure 6); metafemur relatively thin; metatibia thin, weakly curved; metatarsus greatly elongate, segments cylindrical, segments 1 and 5 longest, segment 4 shortest, in combination segments 1 and 2 about as long as others combined, all segments without spines other than at apex; claws very weak.

Female. Pro and meso tibia normal, without triangular extension on inner edge nor enlarged spines.

Male (Figures 2-4). Protibia with thin triangular extension on inside in apical half, inner edge of which with row of closely spaced strong spines; mesotibia with small but well-marked triangular extension in middle of inner edge surmounted by 2-3 strong spines, inner and outer apical spines slightly enlarged.

Median lobe of aedeagus relatively narrow, sides slightly sinuate, apex narrowing to blunt point; paramere broadly triangular, apex turned inwards for short distance, outer edge at apex with 3-4 moderately long setae.

\section{ETYMOLOGY}

Latin. angustus - narrow. A reference to its narrow shape.

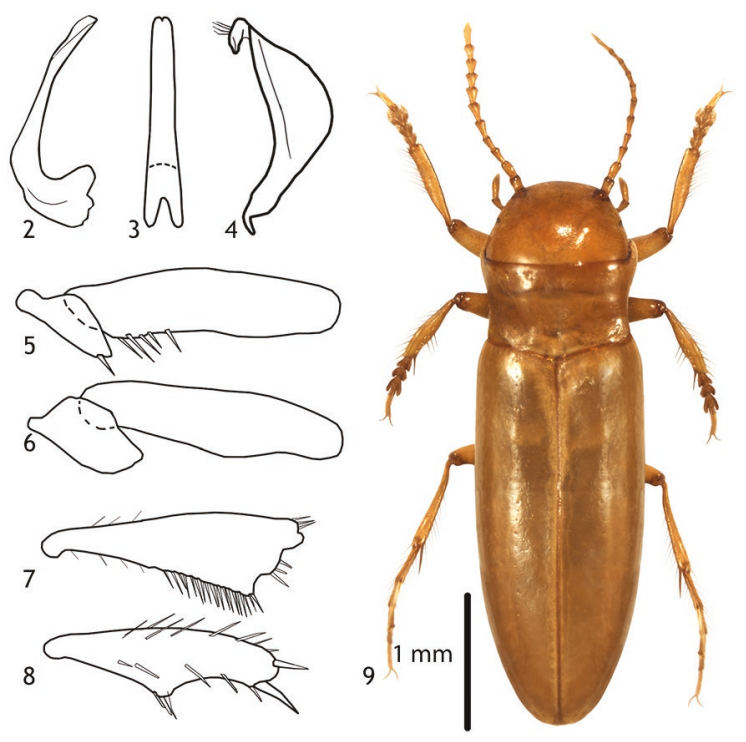

FIGURES 2-9 Paroster angustus sp. nov.; 2, lateral view of median lobe of aedeagus; 3 , ditto dorsal view; 4, paramere; 5, mesotrochanter and mesofemur; 6 , metatrochanter and metafemur; 7, metatibia; 8, protibia; 9, habitus. Scale bar represents $1 \mathrm{~mm}$. (habitus only).

\section{REMARKS}

A large species easily recognized by its very elongate shape, triangular extensions of both the pro and meso tibia in the males and the knobbly antennae caused by the inner and outer swellings on the apex of each segment. In the key given in Watts and Humphreys (2009) Paroster angustus will run to P. macrosturtensis Watts and Humphreys from Sturt Meadows station but differs considerably from it, most notably in the characters mentioned above.

\section{Family Dytiscidae Leach, 1815}

Tribe Bidessini Sharp, 1882

\section{Genus Limbodessus Guignot, 1939}

Limbodessus Guignot 1939: 52.

\section{TYPE SPECIES}

Hydroporus compactus Clark, 1862, by original designation.

\section{DIAGNOSIS}

Limbodessus can be distinguished from other dytiscid genera as follows: length $1.0-3.5 \mathrm{~mm}$, body elongate, without sutural striae, inner margins of metacoxal wings not strongly ridged.

\section{Limbodessus yeelirrieensis sp. nov.}

Figures $10-15$

urn:Isid:zoobank.org:act:C1A60E6F-41EB-4544-83AD4751CC644CC7

\section{MATERIAL EXAMINED}

\section{Holotype}

Australia: Western Australia: Yilgarn, Carey Palaeodrainage, Yeelirrie Station, 1 ते seLN8340, 16Mar-2010 Bore YYAC170, 27¹013.85"S 1195405.92"E, collected by Subterranean Ecology Pty Ltd; WAM R90976.

\section{Paratypes}

Australia: Western Australia: Yilgarn, Carey Palaeodrainage, Yeelirrie Station, all collected by Subterranean Ecology Pty Ltd: 1 o seLN8362, 16-Mar2010 Bore YYAC33, 271010.77"S 1195218.58"E; 1 ` seLN6506, 1-Sep-2009 Bore TPB33-1 2708`01”S 11949`40”E, Genbank Accession No. KU549167; 1 우 seLN8340 16-Mar-2010 Bore YYAC170, 27¹013.85"S $119^{\circ} 5405.92 " \mathrm{E} ; 1$ q seLN6622, 31-Aug-2009 Bore YYD26, 27007.23"S 1195212.42"E; 1 q seLN6615, 1-Sep-2009 Bore YU1, 270833.7"S 1195111.36"E; 1 ते seLN6633 30-Aug-2009 Bore YYAC0016A, $27^{\circ} 0956.67 " \mathrm{~S} 119^{\circ} 5220.14 " \mathrm{E}$, slide. All SAMA. 


\section{Other material}

Australia: Western Australia: Yilgarn, Carey Palaeodrainage, Yeelirrie Station, all collected by Subterranean Ecology Pty Ltd: 1 spec. seLN10:0011b, 17-Sep-2010, Bore YU1, 270833.7"S 1195111.36", Genbank Accession No. KU549164; 1 spec. seLN7650, 11-Jan-2010 and 3 spec. seLN8353, 16-Mar-2010, Bore YYAC0019C, $27^{\circ} 0933.17^{\prime S} 119^{\circ} 5233.77 " E ; 1$ spec. seLN7654, 11-Jan-2010, Bore YYAC1004D, 2701029.4"S 1195238.34"E; 1 spec. seLN8548b, 21-Mar-2010, Bore YYAC1007A, 270949.56"S 1195304.33"E; 2 spec. seLN7423, 12-Nov-2009 and 2 spec. seLN7571, 11-Jan2010, Bore YYAC170, 271013.85"S 1195405.92"E; 1 spec. seLN7436, 12-Nov-2009 and 1 spec. seLN8367, 16-Mar-2010, Genbank Accession No. KU549158, Bore YYAC248, 271020.35"S 1195418.59"E; 1 spec. seLN7378, 12-Nov-2009 and 6 spec. seLN7376, 12-Nov2009, Bore YYAC285, 27¹017.84"S 1195428.4"E; 2 spec. seLN7416, 12-Nov-2009 and 1 spec. seLN7640, 11Jan-2010, Bore YYAC35, 270958.56"S 1195226.36"E; 1 spec. seLN8483b, 15-Mar-2010 and 1 spec. seLN8294, 20-Mar-2010 and 1 spec. seLN8289, 20-Mar-2010, all Bore YYD26, 27¹007.23"S 1195212.42"E; 1 spec. seLN8399, 17-Mar-2010 and 1 spec. seLN10:0456, 17-Sep-2010 Genbank Accession No. KU549163, Bore YYHC0054C, 270814.7"S 1195111.35"E; 1 spec. seLN10:0023, 17-Sep-2010, Bore YYHC0086D, $27^{\circ} 0808.5^{\prime \prime S} 119^{\circ} 5111.27^{\prime \prime E}$; 1 spec. seLN8403b, 17-Mar2010, Bore YYHC0139, 270817.46"S 1195111.31"E. All WAM.

\section{DESCRIPTION}

Habitus. Length 1.9-2.0 mm; relatively flat, weakly constricted at junction of pronotum/elytra; elongate, elytra slightly wider in middle; uniformly light testaceous; hindwing reduced, about a third length of elytron.

Head. A little narrower than elytra; smooth, reticulation weak, punctures sparse, very small; subparallel in posterior half, widest in middle; eye remnant reduced to a single suture. Antenna relatively thin, segments 1 and 2 cylindrical, segment 3 as long as segment 2, narrower, narrowing towards base, segment 4 shorter, segments 5-10 approximately equal in shape, progressively slightly smaller, weakly expanded at apex on inside; segment 11 thinner, about twice length of segment 10, each segment, except segment 1, with some very small setae on inside apically. Maxillary palpus, elongate, segment 4 as long as segments 1-3 combined.

Pronotum. About as wide as elytra; anteriolateral angles projecting strongly forward; weakly constricted just before base, posterolateral angles almost square, overlying elytra somewhat; smooth, reticulation weak, punctures very weak, sparse, a few large ones along anterior margin; without basal plicae other than vague impressions in some lights; with row of long setae laterally in anterior half.

Elytra. Not fused, lacking inner ridges; sides a little wider in middle, smooth, very weakly reticulate, sparsely covered with small punctures; row of larger punctures inwards from suture and a few additional larger punctures with long setae, more frequent towards sides. Epipleuron weakly differentiated from rest of elytron, that portion of elytron visible ventrally, relatively broad in anterior quarter, thin along rest of elytron.

Ventral surface. Prosternal process strongly narrowed between coxae, not reaching mesoventrite, apex arrowshaped, tip pointed, strongly arched in lateral view with highest point (viewed ventrally) between coxae. Anterior margin of mesoventrite in midline sculptured to accept pronotal process. Mesocoxae in contact at midline. Metaventrite triangular in front in midline; wings narrow; rounded in midline behind. Metacoxal plates large, shiny, virtually nonreticulate, metacoxal lines obsolete; closely adpressed to ventrite 1 . Sutural lines between ventrites 1 and 2 reaching sides, ventrites 3-5 mobile, sparsely covered with small seta-bearing punctures, ventrites 3 and 4 with a long central seta or bunch of long setae.

Legs. Protibia bow-shaped, relatively narrow, widest a little beyond centre where it is about three times its basal width; protarsus moderately expanded, segment 1 nearly $2 \mathrm{x}$ as long as broad, segment 2 as wide as segment 1 and about a half its length, lobes well marked, segment 3 longer than segment 1, much narrower deeply bilobed, segment 4 very small, hidden within lobes of segment 3, segment 5 narrow, cylindrical, about length of segment 3, segments 1-3 with covering of adhesive setae; claws relatively long. Mesotrochanter elongate/ rectangular with a few thin setae on inner edge near tip; mesofemur relatively thin, row of 6-7 relatively long spines along basal half, evenly spaced. (Figure 13); mesotarsus similar to protarsus, a little more elongate. Metatrochanter moderately large, tip rounded (Figure 14); metafemur relatively thin, lacking spines; metatibia narrow, quite strongly curved, widening towards apex; metatarsus elongate, segment 1 longest, segment 5 longer than segment 4, segments 1 and 2 in combination about as long as others; claws weak.

Male. Pro and mesotarsi a little broader. Median lobe of aedeagus moderately broad, narrowing near tip, tip blunt; basal segment of paramere relatively broad, apical segment relatively short, broad, apical lobe long, thin, separated from rest of segment, tip rounded, weakly curved forwards (Figures 10-13).

\section{ETYMOLOGY}

Named after the local area and pastoral station on which it was found, the word 'yeelirrie' is an indigenous place name and according to traditional owners it refers to a 'place of death'.

\section{REMARKS}

A small species morphologically similar to the other new species described here, L. odysseus from the same calcrete, in its general morphology and in the form of the male genitalia but differs from it by its greater size, larger number of spines on the mesofemur and the form 

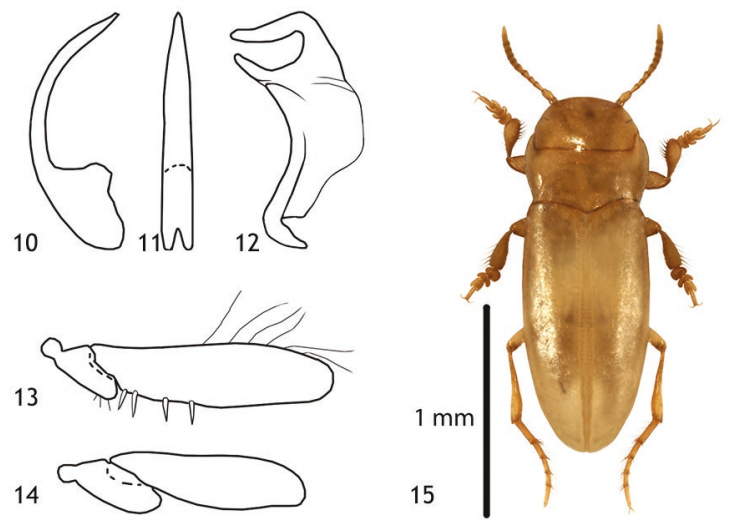

FIGURES 10-15 Limbodessus yeelirrieensis sp. nov.; 10, lateral view of median lobe of aedeagus; 11, ditto dorsal view; 12, paramere; 13, mesotrochanter and mesofemur; 14, metatrochanter and metafemur; 15, habitus. Scale bar represents $1 \mathrm{~mm}$. (habitus only).

of the apical segment of the paramere. Limbodessus yeelirriensis will run to $L$. phoebeae from Yakabindie Station in the key given by Watts and Humphreys (2009) but it is smaller, the base of the pronotum is less strongly constricted, the spines on the mesofemur are longer, the protibia narrower and the apical lobe of the paramere shorter.

\section{Limbodessus odysseus sp. nov.}

Figures 16-21

urn:Isid:zoobank.org:act:35304BD4-2608-4970-A510C33EE2965A27

\section{MATERIAL EXAMINED}

\section{Holotype}

Australia: Western Australia: Yilgarn, Carey Palaeodrainage, Yeelirrie Station, 1 त seLN8557, 21-Mar-2010, Bore YYAC1004C, 2701024.13"S $119^{\circ} 5243.51^{\prime \prime E}$, collected by Subterranean Ecology Pty Ltd, WAM R90977.

\section{Paratypes}

Australia: Western Australia: Yilgarn, Carey Palaeodrainage, Yeelirrie Station, all collected by Subterranean Ecology Pty Ltd: 1 đิ seLN8403 17-Mar2010 Bore YYHC0139, $27^{\circ} 08$ 17.46"S 1195111.31"E; 1 ก seLN8541, 21-Mar-2010, Bore YYAC118, $27^{\circ} 1028.8^{\prime \prime S ~ 119 \circ 5323.06 " E ; ~} 2$ ô partial, seLN6621 1-Sep-2009 Bore YU2, 270814.15"S 119 5111.41"E, slide; 1 seLN6593 30-Aug-2009 Bore YYAC0016A, 270956.67"S 1195220.14"E, Genbank Accession No. KU549168.All SAMA.

\section{Other material}

Australia: Western Australia: Yilgarn, Carey Palaeodrainage, Yeelirrie Station, all collected by Subterranean Ecology Pty Ltd: 1 spec. seLN6478, 10-Mar-2009 and 9 spec. (elytra) seLN6479, 10-Mar2009, and 2 spec. seLN8507, 15-Mar-2010, Genbank Accession No. KU549166, Bore TPB33-1, 270801.8"S 1194940.38"E; 1 spec. seLN10:0011a, 17-Sep-2010, Bore YU1, 270833.7"S 1195111.36"E, Genbank Accession No. KU549160; 1 spec. seLN6590, 30-Aug2009, Bore YYAC0014A, 27¹108.72"S 1195545.18"E; 1 spec. seLN8386, 17-Mar-2010, Bore YYAC0014D, $27^{\circ} 1108.17^{\prime \prime S} 119^{\circ} 5545.31^{\prime \prime E}$; 1 spec. seLN6648, 12-Nov2009, Bore YYAC0019C, 270933.17"S 1195233.77"E; 1 spec. seLN7653, 11-Jan-2010, Bore YYAC1004D, $27^{\circ} 1029.4^{\prime S} 119^{\circ} 5238.34^{\prime \prime E} ; 1$ spec. (exoskeleton) seFN9385, 21-Mar-2010, Bore YYAC1005B, 27¹046.02"S 1195228.92"E; 1 spec. seLN9803, 16-Mar2010, Bore YYAC1006B, 270941.91"S 1195311.9"E; 1 spec. seLN7387 and 1 spec. seLN7386, 12-Nov-2009 and Bore YYAC118, 27028.8"S 119 5323.06"E; 1 spec. seLN7678, 11-Jan-2010, Bore YYAC170, 27013.85"S $119^{\circ} 5405.92^{\prime \prime E} ; 1$ spec. seLN7682, 11-Jan-2010, Bore YYAC328, 271032.5"S 119 5427.62"E; 1 spec. seLN10:0426, 24-Sep-2010 and 1 spec. seLN7641, 11Jan-2010, Bore YYAC35, 270958.56"S 1195226.36"E; 1 spec. seLN8454, 18-Mar-2010, Bore YYHC0048KA, $27^{\circ} 1451.51 " \mathrm{~S} 120^{\circ} 0317.46 " \mathrm{E}$, Genbank Accession No. KU549170; 1 spec. seLN10:0377, 22-Sep-2010, Bore YYHC0118A, 270207.98"S 1194257.41"E, Genbank Accession No. KU549165; 1 spec. seLN10:0429, 17-Sep2010, Bore YYHC0118B, 270207.63"S 1194257.29"E, Genbank Accession No. KU549159; 1 spec. seLN8403a, 17-Mar-2010, Bore YYHC0139, 270817.46"S 1195111.31"E. All WAM.

\section{DESCRIPTION}

Habitus. Length $1.7 \mathrm{~mm}$; relatively flat, weakly constricted at junction of pronotum/elytra; elongate, elytra slightly wider in middle; uniformly light testaceous; hindwing reduced, about a third length of elytron.

Head. A little narrower than elytra; smooth, reticulation weak, punctures sparse, very small; subparallel in posterior half, widest in middle; eye remnant reduced to a single suture. Antenna relatively stout, segment 1 cylindrical, segment 2 barrel-shaped, segment 3 a little shorter than segment 2, narrower, narrowing towards base, segment 4 shorter, segments 5-10 relatively broad, approximately equal in shape, weakly expanded at apex on inside; segment 11 thinner, about twice length of segment 10 , each segment, except segment 1 , with some very small setae on inside apically. Maxillary palpus, elongate, segment 4 as long as segments 1-3 combined.

Pronotum. About as wide as elytra; anteriolateral angles projecting strongly forward; weakly constricted just before base, posterolateral angles projecting slightly backwards, overlying elytra somewhat; smooth, reticulation weak, punctures very weak, sparse, a few 
large ones along anterior margin; without basal plicae other than vague impressions in some lights; with row of long setae laterally in anterior half.

Elytra. Not fused, lacking inner ridges; sides a little wider in middle, smooth, very weakly reticulate, sparsely covered with small punctures; row of larger punctures inwards from suture and a few additional larger punctures with long setae, more frequent towards sides. Epipleuron weakly differentiated from rest of elytron, that portion of elytron visible ventrally, relatively wide in anterior quarter, thin along rest of elytron.

Ventral surface. Prosternal process strongly narrowed between coxae, not reaching mesoventrite, apex sides subparallel, narrowing to blunt tip, strongly arched in lateral view with highest point (viewed ventrally) between coxae. Anterior margin of mesoventrite in midline sculptured to accept pronotal process. Mesocoxae in contact at midline. Metaventrite triangular in front in midline; wings narrow; midline behind narrowly rounded. Metacoxal plates large, shiny, virtually nonreticulate, metacoxal lines obsolete; closely adpressed to ventrite 1 . Sutural lines between ventrites 1 and 2 reaching sides, ventrites 3-5 mobile, sparsely covered with small seta-bearing punctures, ventrites 3 and 4 with a long central seta or bunch of long setae.

Legs (female). Protibia bow-shaped, relatively narrow, widest a little beyond centre where it is about four times its basal width; protarsus moderately expanded, segment 1 about as long as broad, segment 2 as wide as segment 1 and about a half its length, bilobed, segment 3 longer than segment 1 , about as wide, deeply bilobed, segment
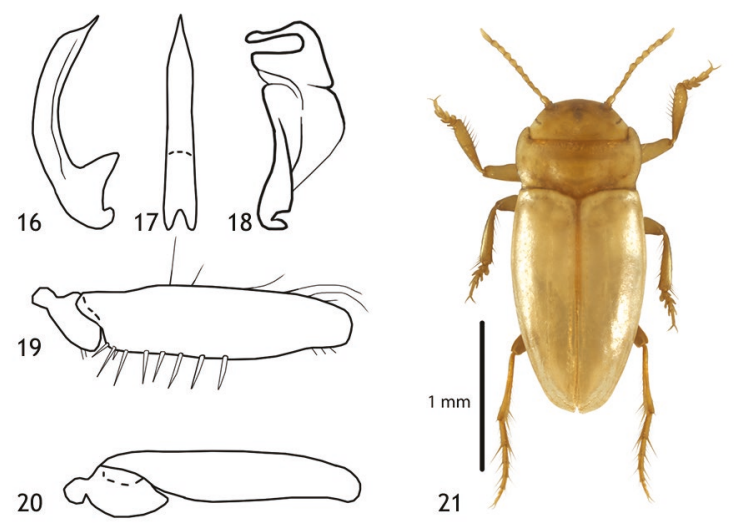

FIGURES 16-21 Limbodessus odysseus sp. nov.; 16, lateral view of median lobe of aedeagus; 17, ditto dorsal view; 18, paramere; 19, mesotrochanter and mesofemur; 20, metatrochanter and metafemur; 21, habitus. Scale bar represents $1 \mathrm{~mm}$. (habitus only).
4 very small, hidden within lobes of segment 3 , segment 5 narrow, cylindrical, a little longer than segment 3, segments 1-3 with covering of adhesive setae; claws relatively long. Mesotrochanter elongate/rectangular with a few thin setae on inner edge near tip; mesofemur relatively broad with row of 4 spines along basal half, evenly spaced. (Figure 19); mesotarsus less expanded than protarsus. Metatrochanter relatively large, tip rounded (Figure 20); metafemur relatively thin, lacking spines; metatibia narrow, quite strongly curved, widening towards apex; metatarsus elongate, segment 1 longest, segment 5 longer than segment 4 , segments 1 and 2 in combination about as long as others; claws weak.

Male. Legs as for female except pro and mesotarsi a little broader. Median lobe of aedeagus moderately broad, sides subparallel narrowing rapidly near tip, tip blunt; basal segment of paramere moderately broad, apical segment relatively short, broad, apical lobe long, thin, well separated from rest of segment, tip weakly curved backwards meeting extended lobe of basal portion of apical segment forwards (Figures 16-18).

\section{ETYMOLOGY}

Named after the Greek hero Odysseus, in Homer's Illiad and the Odyssey.

\section{REMARKS}

Morphologically very similar to Limbodessus yeelirrieensis described above from the same calcrete but it can be separated from this species by its smaller size, fewer spines on the mesofemur, less strongly lobed pro and mesotarsi and a rather differently shaped apical segment of the paramere (Figures 9, 12). In the key given in Watts and Humphreys (2009) Limbodessus odysseus will run to L. lapostaae Watts and Humphreys from Laverton Downs Station but is a bit larger, the pronotum less constricted and the lobes of the apical segment of the paramere thinner and more separate from each other.

\section{KEY TO THE SPECIES OF DYTISCIDAE FOUND IN YEELIRRIE CALCRETES}

1. Length $>3.0 \mathrm{~mm}$; very elongate; pro and mesotibia triangularly produced on inside edge, metatibia only slightly expanding towards apex.

Paroster angustus sp. nov.

Length $<2.5 \mathrm{~mm}$; elongate/oval; pro and mesotibia not produced, metatibia strongly expanded towards apex

2. Length approximately $1.7 \mathrm{~mm}$; mesofemur with 4 spines on rear edge in basal half.

Limbodessus odysseus sp. nov.

Length approximately $2.0 \mathrm{~mm}$; mesofemur with 6-7 spines along rear edge in basal half .....

Limbodessus yeelirrieensis sp. nov. 


\section{DNA SEQUENCING}

The genetic analyses validated the designation based on morphological characteristics of two new species of Limbodessus and one new species of Paroster. Inter-specific sequence divergences between the two Limbodessus spp. ranged from 7.54 to $10.65 \%$, and 16.98 to $20.71 \%$ between Paroster angustus and Limbodessus spp. (uncorrected p distance of CO1 'barcoding' region, Table 2). Intraspecific sequence divergence was low in L. yeelirrieensis; three specimens sequenced from three bores (situated within $6 \mathrm{~km}$ of each other in the central calcrete) differed by 0.00 to $1.22 \%$. Sequence divergence was higher in L. odysseus; four specimens sequenced from four geographically dispersed bores (separated from each other by distances ranging from 3 to $43.5 \mathrm{~km}$ and spanning the northwest, central and southeast calcretes) differed by 0.50 to $4.01 \%$ (Table 2, Figure 1).

\section{DISCUSSION}

\section{GENETICS}

The small number of specimens DNA sequenced during this study limit the interpretation of phylogeographic and population genetic patterns within the Yeelirrie calcretes, however the relatively high sequence divergence (4.01\%, Table 2$)$ observed in L. odysseus shows high phylogenetic variation across the $44 \mathrm{~km}$ range of this species which spans the geologically discontinuous northwest, central and southeast calcretes. This indicates large and long term stable population size of this species across its range. Genetic variation among sympatric dytiscid species has been studied at fine spatial scale within the Sturt Meadows calcrete where even within a $3.5 \mathrm{~km}^{2}$ grid of bores all three species exhibited high levels of haplotype diversity and spatial heterogeneity in the distribution of genetic variation and abundance (Guzik et al. 2009).

Regionally, the two Limbodessus species from Yeelirrie are more closely related to species from other calcretes than to each other. The closest sister species to L. yeelirriensis sp. n. are L. phoebeae from Lake Miranda calcrete (Carey palaeochannel) and L. gumwellensis from Perrinvale calcrete (Raeside palaeochannel). However, these three species were only moderately related at approximately $5.1-6.7 \%$ sequence divergence (COI). The nearest sister species to L. odysseus sp. n. (at approx. 5.6-8.2\% COI) were $L$. nambiensis from Nambi calcrete (Carey palaeochannel) and L. surreptitius from Challa calcrete (Murchison palaeochannel) (Watts and Humphreys 2006). Paroster angustus appears to have more distantly related sister species, including P. melroseensis and P. darlotensis from the Melrose Station/ Lake Darlot calcrete in the lower Carey palaeodrainage (7.8-9.4\% sequence divergence $\mathrm{COI}$ ), and an undescribed species at Belele calcrete in the Murchison (9.4\%).

The phylogenetic relationships and evolution of the Yilgarn Limbodessus and Paroster species has been studied in detail (Leys et al 2003; Leys and Watts 2008; Guzik et al. 2009; Leijs et al 2012), suggesting that most diving beetle species in individual calcrete aquifers originated from independent colonisations of a restricted number of widespread surface species, that subsequently evolved different body sizes under selection pressure to fit the subterranean ecological niche space (Vergnon et al 2013). The three new species from the Yeelirrie calcretes fit within the above described evolutionary pattern. Currently, there is no clear understanding of specific niche differences among dytiscid taxa, however we consider it probable that habitat structure especially matrix porosity (size and connectivity) and water physico-chemistry (salinity) may be important.

\section{DISTRIBUTION PATTERNS}

All three species qualify as short range endemics (sensu Harvey 2002; Harvey et al. 2011) with their distributions restricted to the series of semidiscontinuous groundwater calcrete islands comprising the greater Yeelirrie calcrete archipelago which has a linear extent of approximately 60 kilometres. The wider recorded distribution range for Limbodessus odysseus, which extended to the northwest and southeast calcretes is notable. Although the occurrence of P. angustus and $L$. yeelirriensis at the northwest and southeast calcretes cannot be precluded considering the overall low detectability of these dytiscids $(4.3 \%$ and $5.8 \%$ of 257 sampled bores respectively and $3.6 \%$ and $3.9 \%$ of 642 samples), we suggest that the distribution range of $P$. angustus and L. yeelirriensis is probably confined to the central calcrete.

The wider distribution of L. odysseus may be explained by its small size which may facilitate its dispersal and colonisation of interstitial or sub-karstic calcrete habitats, although the size difference between L. odysseus and L. yeelirriensis is fairly minor $(1.7 \mathrm{~mm}$ body length vs 1.9 to $2.0 \mathrm{~mm}$ ) Small-sized dytiscids are not restricted to karstic subterranean habitats and in Australia they have been found in alluvial aquifers, for example, Carabhydrus stephanieae from the Pages River and Dart Brook alluviums in the upper Hunter Valley, New South Wales (Watts et al. 2007).

The survey results across all stygofauna taxa indicate that the central calcrete is a localised diversity hotspot supporting from 1.5 to $2 \mathrm{x}$ the number of species compared with the other Yeelirrie calcretes (Subterranean Ecology 2011). This interpretation is consistent with an additional survey (66 samples) which aimed to show the wider distribution of stygofauna species currently only known from areas of predicted groundwater drawdown (Bennelongia 2015). This survey, concentrated in the central calcrete and adjacent palaeochannel sediments outside of areas of predicted groundwater drawdown, recorded 15 additional stygofauna species not recorded in earlier surveys, but no supplementary findings of $P$. angustus and $L$. yeelirriensis. 
The central calcrete evidently provides optimum habitat for stygofauna and perhaps also contains a greater diversity of specialised ecological niches (e.g. differing in salinity) thus permitting more species to occupy the area. Additionally, this calcrete may have inherently greater buffering capacity against environmental changes over time owing to its relatively large size and therefore it might be expected to maintain a more stable subterranean environment than the smaller calcretes. The northwest, central and southeast calcrete bodies are separated by intervening geology of palaeochannel alluvium /colluvium, however it is not impossible that the calcrete bodies were geologically connected in the past, or that fluctuating groundwater levels and interstitial habitat connectivity has enabled past or contemporary dispersal by some of the subterranean species in the Yeelirrie calcretes. The few sequence data available shows maximum as well as minimum divergences between NW-central and central-SE, which may indicate both old and more recent connectivity. These concepts are supported by the complex speciation and distribution patterns (sympatry, parapatry, allopatry) observed for multiple copepod taxa described from Yeelirrie which suggest an evolutionary history involving multiple colonisation and speciation episodes within this area of patchy and heterogeneous groundwater habitat (Karanovic and Cooper 2011a, b, 2012; Karanovic et al. 2015, 2016).

\section{GROUNDWATER ENVIRONMENT}

The groundwater physico-chemistry demonstrated that the Yeelirrie dytiscids can tolerate a considerable range in salinity, with EC values ranging from 2.3 to $37.1 \mathrm{mS} / \mathrm{cm}$ (Table 2). Dytiscids appear to be less tolerant of more saline conditions than some other stygofaunal taxa at Yeelirrie, including parabathynellid syncarids and harpacticoid copepods which were collected from bores with recorded EC values of 57.3 and $73.7 \mathrm{mS} / \mathrm{cm}$ respectively (Subterranean Ecology 2011 unpublished data). Salinity is an important factor influencing stygofauna diversity and abundance, and many taxa are intolerant of high salinities, however the Yilgarn stygofauna in particular is notable for the high salinity tolerance exhibited by taxa more typically found in 'fresh' groundwater environments Humphreys (2008).

The high capture success using the scraping method, which involves dipping the net just below the bore water surface (whereas the net haul method drags the entire bore water column) suggests that dytiscids are congregating near the water surface in bores. This finding is not unexpected given that all water beetles need to regularly return to a free air surface to breath. Bores also act as pitfall traps for surface invertebrates, which may accidentally fall onto the water surface and become potential prey for dytiscids.

\section{IMPLICATIONS FOR ENVIRONMENTAL IMPACT ASSESSMENT}

The localised heterogeneity in distribution of dytiscids and other stygofauna (most notably copepods, Karanovic and Cooper 2011a, b; 2012; Karanovic et al. 2015, 2016) observed in the greater Yeelirrie calcrete was revealed only through concentrated field survey efforts combined with thorough taxonomic scrutiny including DNA sequencing (Subterranean Ecology 2011). The survey effort applied in this study exceeded by 3 to $4 \mathrm{x}$ the minimum number of samples and sample events recommended by the EPA (2007) for environmental impact assessment (EIA). The results of this survey clearly indicate that substantially greater survey effort than typically practised in most pre-mining surveys conducted in Western Australia is required to give confidence in EIA of stygofauna, and this proviso

TABLE 2 Pairwise uncorrected p distances of CO1 of 'barcoding' region. Species are labelled using the first letter of their genus and species name respectively. Intra-specific distances of Limbodessus yeelirriensis (Ly) and L. odysseus (Lo) are bolded (and see Figure 1).

\begin{tabular}{llllllllll}
$\begin{array}{l}\text { Survey } \\
\text { Sector }\end{array}$ & $\begin{array}{l}\text { Species } \\
\text { (hole identifier) }\end{array}$ & $\begin{array}{l}\text { Ly } \\
\text { (54C) }\end{array}$ & $\begin{array}{l}\text { Ly } \\
\text { (YU1) }\end{array}$ & $\begin{array}{l}\text { Ly } \\
(33-1)\end{array}$ & $\begin{array}{l}\text { Lo } \\
(118 \mathrm{~A})\end{array}$ & $\begin{array}{l}\text { Lo } \\
(33-1)\end{array}$ & $\begin{array}{l}\text { Lo } \\
(48 \mathrm{~K})\end{array}$ & $\begin{array}{l}\text { Lo } \\
\text { (16A) }\end{array}$ & $\begin{array}{l}\text { Pa } \\
\text { (YU2) }\end{array}$ \\
\hline Central & Ly (54C) & & & & & & & \\
Central & Ly (YU1) & $\mathbf{0 . 0 0}$ & & & & & & \\
Central & Ly (33-1) & $\mathbf{1 . 1 2}$ & $\mathbf{1 . 2 2}$ & & & & & \\
North-west & Lo (118A) & 8.30 & 8.22 & 9.64 & & & & \\
Central & Lo (33-1) & 7.57 & 7.54 & 9.08 & $\mathbf{1 . 6 1}$ & & & \\
Central & Lo (16A) & 9.98 & 9.27 & 10.65 & $\mathbf{4 . 0 1}$ & $\mathbf{2 . 4 8}$ & & \\
South-east & Lo (48K) & 8.46 & 7.69 & 9.23 & $\mathbf{2 . 1 3}$ & $\mathbf{0 . 5 0}$ & $\mathbf{1 . 2 0}$ & \\
Central & Pa (YU2) & 20.71 & 21.00 & 20.18 & 19.49 & 18.71 & 19.23 & 16.98 \\
\hline
\end{tabular}


applies both in regions where stygofauna is known to be diverse and abundant such as the northern Yilgarn calcretes, as well as regions where stygofauna is less diverse and abundant such as the southern Yilgarn (see Karanovic et al. 2013).

\section{IMPACT OF PROPOSED MINE AND AQUIFER DEWATERING}

The Yeelirrie mine development will result in permanent loss of $17 \%$ (by area) of the PEC through excavation, and $42 \%$ of the saturated calcrete habitat will experience drawdown of $-0.5 \mathrm{~m}$ or greater (Cameco Pty Ltd 2016). Of the 73 stygofauna species recorded, nearly all (except four) appear to be short-range endemics restricted to the Yeelirrie calcrete and adjacent palaeochannel sediments (Cameco Pty Ltd 2015, 2016). To reduce the impact Cameco propose to strategically locate production supply wells in the areas north of the valley floor and north of the proposed pit, away from areas of preferred stygofauna habitat (Figure 1). Prior to Project commencement Cameco have also committed to develop a Subterranean Fauna Management Plan which will include a monitoring program and the setting of trigger criteria and contingency actions (Cameco Pty Ltd 2015, 2016). Despite these measures, the proposed mine pit and aquifer drawdown to $-0.5 \mathrm{~m}$ or greater will impact $42 \%$ of the core stygofauna habitat and around $60 \%$ of the recorded distribution range of Paroster angustus and Limbodessus yeelirrieensis (Figure 1). The impact of this amount of habitat removal and water table lowering on the long term viability of the surviving populations of these two dytiscid species, and their associated stygofauna community, is unknown and cannot be predicted with any confidence.

\section{ACKNOWLEDGEMENTS}

The species described herein were collected as part of the Yeelirrie Subterranean Fauna Survey 2009-2011 commissioned by BHP Billiton Yeelirrie Development Company Pty Ltd whom we gratefully acknowledge for funding and support of the field survey work. We also acknowledge URS Australia Pty Ltd, particularly Kim Ferguson (nee Drummond), who helped coordinate the field surveys and assisted with logistics and administrative support. For field and laboratory assistance we thank Peter Bell, Giulia Perina, Natalie Krawczyk, Steven Catomore, Rujiporn Thavornkanlapachai, Natasha Coen, Sasha Voss and Tom Karanovic (all Subterranean Ecology Pty Ltd). Dr Terrie Finston and Dr Oliver Berry of Helix Molecular Solutions undertook the initial genetic analyses. The Western Australian Museum contributed regional records. Howard Hamon is thanked for enhancing the taxonomic photographic images and preparing the line drawings. Helpful comments received from two referees are acknowledged and appreciated.

\section{REFERENCES}

Abrams, K. M., Guzik, M. T., Cooper, S. J. B., Humphreys, W. F., King, R.A., Cho, J-L. and Austin, A.D. (2012). What lies beneath: Molecular phylogenetics and ancestral state reconstruction of the ancient subterranean Australian Parabathynellidae (Syncarida, Crustacea). Molecular Phylogenetics and Evolution 64(1): 1-15.

Aube, C (1836). Hydrocanthares. In: Dejean, P.F. Iconographie et histoire naturelle des coleopteres d'Europe 5: 84.

Bennelongia (2015). Yeelirrie Subterranean Fauna Assessment. Report prepared for Cameco Australia Pty Ltd. 36 pp.

Bradford, T., Adams, M., Humphreys, W. F., Austin, A. D., and Cooper, S. J. B. (2010). DNA barcoding of stygofauna uncovers cryptic amphipod diversity in a calcrete aquifer in Western Australia's arid zone. Molecular Ecology Resources 10: 41-50.

Cameco Australia Pty Ltd (2015). Yeelirrie Uranium Project Public Environmental Review, Section Nine: Environmental Factors, 9.2 Subterranean Fauna. pp. 173-197. https:// www.cameco.com/australia/pdf/yeelirrie/per_documents/ Cameco\%20Yeelirrie\%20PER\%20Section\%209.2\%20-\%20 Subterranean\%20Fauna.pdf (viewed 31/12/2015).

Cameco Australia Pty Ltd (2016). Yeelirrie Uranium Project Response to Submissions, Attachment 3: Revised subterranean fauna avoidance, minimization, mitigation and offset measures. http://www.epa.wa.gov.au/EIA/ EPAReports/Documents/1574/Attachment\%203\%20-\%20 Revised $\% 20$ subterranean $\% 20$ fauna $\% 20$ avoidance, $\% 20$ minimisation, $\% 20$ mitigation $\% 20$ and $\% 20$ offset $\% 20$ measures.pdf (viewed 24/08/2016).

Clark, H. (1862). Catalogue of the Dytiscidae and Gyrinidae of Australsia with descriptions of new species. The Journal of Entomology Descriptive and Geographical 1: 399-421.

Cooper, S. J. B, Bradbury, J. H., Saint, K. M., Leys, R., Austin, A. D., and Humphreys, W. F. (2007). Subterranean archipelago in the Australian arid zone: mitochondrial DNA phylogeography of amphipods from central Western Australia. Molecular Ecology 16: 1533-1544.

Cooper, S. J. B., Hinze, S., Leys, R., Watts, C. H. S., and Humphreys, W. F. (2002). Islands under the desert: molecular systematics and evolutionary origin of stygobitic water beetles (Coleoptera: Dytiscidae) from central Western Australia. Invertebrate Systematics 16: 589-598.

Cooper, S. J. B., Saint, K. M., Taiti, S., Austin, A. D., and Humphreys, W. F. (2008). Subterranean archipelago: mitochondrial DNA phylogeography of stygobitic isopods (Oniscidea: Haloniscus) from the Yilgarn region of Western Australia. Invertebrate Systematics 22: 195-203.

Department of Parks and Wildlife (2014) Priority ecological communities for Western Australia version 21, Species and Communities Branch, 25 November 2014. https:// www.dpaw.wa.gov.au/images/documents/plants-animals/ threatened-species/Listings/Priority_ecological_ communities_list.pdf. (viewed 4/5/2016).

Eberhard, S. M., Halse, S. A., Williams, M. R., Scanlon, M. D., Cocking, J., and Barron, H. J. (2009). Exploring the relationship between sampling efficiency and short-range endemism for groundwater fauna in the Pilbara region, Western Australia. Freshwater Biology 54: 885-901.

EPA (2007). Sampling methods and survey considerations for subterranean fauna in Western Australia (Technical Appendix to Guidance Statement No. 54). Guidance Statement 54 A (Draft). Environmental Protection Authority, Government of Western Australia: Perth. 
Guignot, F. (1939). Contribution a l'etude des Bidessus. Bulletin de la Societe d'Etude des Sciences Naturelles de Vaucluse 10: $51-61$.

Guignot, F. (1946). Genotypes des Dytiscoidea et des Gyrinoidea. Revue Francaise d'Entomologie 13: 112-118.

Guzik, M. T., Abrams, K. M., Cooper, S. J. B., Humphreys, W. F., Cho, J-L. and Austin A. D. (2008). Phylogeography of the ancient Parabathynellidae (Crustacea: Bathynellacea) from the Yilgarn region of Western Australia. Invertebrate Systematics 22: 205-216.

Guzik, M.T., Cooper, S. J. B., Humphreys, Austin, A. D. (2009) Fine-scale comparative phylogeography of a sympatric sister species triplet of subterranean diving beetle from a single calcrete aquifer in Western Australia. Molecular Ecology 18: 3683-3698.

Guzik, M.T., Austin, A. D., Cooper, S. J. B., Harvey, M. S., Humphreys, W. F., Bradford, T., Eberhard, S. M., King, R. A., Leys, R., Muirhead, K. A. and Tomlinson, M. (2011). Is the Australian subterranean fauna uniquely diverse? Invertebrate Systematics 24: 407-418.

Halse, S. A. and G. B. Pearson (2014). Troglofauna in the vadose zone: comparison of scraping and trapping results and sampling adequacy. Subterranean Biology 13: 17-34.

Harvey, M. (2002). Short-range endemism among the Australian fauna: some examples from non-marine environments. Invertebrate Systematics 16: 555-570.

Harvey, M. S., M. Rix, Framenau, V. W., Hamilton, Z., Johnson, M. S., Teale, R., Humphreys, G. and Humphreys, W. F. (2011). Protecting the innocent: studying short-range endemic taxa enhances conservation outcomes. Invertebrate Systematics 25: 1-10.

Humphreys, W. F. (2008). Rising from Down Under: developments in subterranean biodiversity in Australia from a groundwater perspective. Invertebrate Systematics 22: 85-101.

Karanovic, I. (2008). A new species of the genus Candonopsis (Crustacea, Ostracoda) from Western Australia. Records of the Western Australian Museum 24: 41-419.

Karanovic, T. and Cooper, S. J. B. (2011a). Molecular and morphological evidence for short range endemism in the Kinnecaris solitaria complex (Copepoda: Parastenocarididae), with descriptions of seven new species. Zootaxa 3026: 1-64.

Karanovic, T. and Cooper, S. J. B. (2011b). Third genus of parastenocaridid copepods from Australia supported by molecular evidence (Copepoda, Harpacticoida). In Defaye, D., Suarez-Morales, E. and von Vaupel Klein, J.C. (eds) Crustaceana Monographs, Studies on Freshwater Copepoda, a volume in honour of Bernard Dussart. Brill: 293-337.

Karanovic, T. and Cooper, S. J. B. (2012). Explosive radiation of the genus Schizopera on a small subterranean island in Western Australia (Copepoda : Harpacticoida): unravelling the cases of cryptic speciation, size differentiation and multiple invasions. Invertebrate Systematics 26: 115-192.

Karanovic, T., Eberhard, S.M., Perina, G. and Callan, S. (2013). Two new subterranean ameirids (Crustacea : Copepoda : Harpacticoida) expose weaknesses in the conservation of short-range endemics threatened by mining developments in Western Australia. Invertebrate. Systematics 27: 540-566.

Karanovic, T., Eberhard, S.M., Cooper, S. J. B., Guzik, M.T. (2015). Morphological and molecular study of the genus Nitokra in a small palaeochannel in Western Australia
(Cructacea: Copepoda : Harpacticoida). Organisms, Diversity and Evolution 15(1): 65-99.

Karanovic, T., Djurakic, M. and Eberhard, S.M. (2016). Cryptic species or inadequate taxonomy? Implementation of 2D geometric morphometrics based on integumental organs as landmarks for delimitation and description of copepod taxa. Systematic Biology 65(2): 304-327.

King, R. A., Bradford, T., Austin, A. D., Humphreys, W. F. and Cooper, S. J. B. (2012). Divergent Molecular Lineages and non-so-cryptic species: the first descriptions of stygobitic chiltoniid amphipods (Talitroidea: Chiltoniidae) from Western Australia. Journal of Crustacean Biology 32(3): 465-488.

Leach W.E. (1815). Entomology. In: Brewster D. Edinburgh Encyclopaedia 9: 57-172.

Leys, R. and Watts, C. H. (2008). Systematics and evolution of the Australian subterranean hydroporine diving beetles (Dytiscidae), with notes on Carabhydrus. Invertebrate Systematics 22: 217-225.

Leys, R., Watts, C. H. S., Cooper, S. J. B. and Humphreys, W. F. (2003). Evolution of subterranean diving beetles (Coleoptera: Dytiscidae: Hydroporini, Bidessini) in the arid zone of Australia. Evolution 57: 2819-2834.

Leijs, R., van Nes, E.H., Watts, C.H.S., Cooper, J.B., Humphreys, W.F. and Hogendoorn, K. (2012). Evolution of blind beetles in isolated aquifers: a test of alternative modes of speciation. Plos One 7(3): 1-8.

Mann, A. W. and Horwitz, R. C. (1979). Groundwater calcrete deposits in Australia: some observations from Western Australia. Journal of the Geological Society of Australia 26: 293-303.

Morgan, K. H. (1993). Development, sedimentation and economic potential of palaeoriver systems of the Yilgarn craton of Western Australia. Sedimentary Geology 85: $637-656$.

Subterranean Ecology Pty Ltd (2011) Yeelirrie Subterranean Fauna Survey. Report prepared for BHP Billiton Yeelirrie Development Company Pty Ltd. 88 pp. +11 appendices.

Taiti, S. and W. F. Humphreys (2001). New aquatic Oniscidea (Crustacea: Isopoda) from groundwater calcretes of Western Australia. Records of the Western Australian Museum, Supplement 64: 133-151.

Vergnon, R., Leijs, R., van Nes, E. H. and Scheffer, M. (2013). Repeated parallel evolution reveals limiting similarity in subterranean diving beetles. American Naturalist 182: $67-75$.

Watts, C.H.S., Hancock, P. J. and Leys, R. (2007). A stygobitic Carabhydrus Watts (Dytiscidae, Coleoptera) from the Hunter Valley in New South Wales, Australia. Australian Journal of Entomology 46: 56-59.

Watts, C. H. S. and Humphreys, W. F. (1999). Three new genera and five new species of Dytiscidae (Coleoptera) from underground waters in Australia. Records of the South Australian Museum 32(2): 121-142.

Watts, C.H.S. and Humphreys, W.F. (2009). Fourteen new Dytiscidae (Coleoptera) of the genera Limbodessus Guignot, Paroster Sharp, and Exocelina Broun from underground waters in Australia. Transactions of the Royal Society of South Australia 133: 62-107.

MANUSCRIPT RECEIVED 22 JUNE 2016; ACCEPTED 12 SEPTEMBER 2016 